\title{
The Contribution of Principal Transformational Leadership, Work Motivation, Through Satisfaction with OCB Teachers
}

Heri Febriani ${ }^{*}$, Aslamiah ${ }^{\mathrm{I}}$, Muhammad Saleh ${ }^{\mathrm{I}}$, Ishak Sin ${ }^{2}$

${ }^{\mathrm{I}}$ Master Program of Educational Management, Universitas Lambung Mangkurat, Banjarmasin 70I23, Indonesia

${ }^{2}$ Senior Lecturer, School of Education and Modern Language, Universiti Utara Malaysia

\begin{tabular}{|c|c|}
\hline ARTICLE INFO & A B S T R ACT \\
\hline \multirow[t]{2}{*}{$\begin{array}{l}\text { Article history } \\
\text { Submission: November } \\
\text { 20I9 } \\
\text { Revised: March } 2020 \\
\text { Accepted: March } 2020 \\
\text { Keywords: } \\
\text { transformational } \\
\text { leadership, job satisfaction, } \\
\text { work motivation, OCB }\end{array}$} & $\begin{array}{l}\text { The purpose of this research is to analyze the influence of leadership, motivation, } \\
\text { and satisfaction on Organizational Citizenship Behavior (OCB). It uses a } \\
\text { quantitative approach with a population of II4 taken by proportionate sampling } \\
\text { from I59 individuals in } 6 \text { Tanjung Redeb Junior High School in East Kalimantan. } \\
\text { Data were collected using a questionnaire and tested for validity and reliability, the } \\
\text { resulting regression model has been tested classic assumptions including normality, } \\
\text { multicollinearity, linearity, and heteroscedasticity tests, then analyzed with } \\
\text { descriptive statistics and path analysis through calculations using SPSS. The results } \\
\text { showed that there was an influence of leadership motivation on satisfaction with } \\
\text { OCB. Generally, satisfaction was the intermediary between the leadership and } \\
\text { OCB; leadership and motivation. }\end{array}$ \\
\hline & $\begin{array}{l}\text { (C) (1) } 2019 \text { The Authors. Journal of K6, Education, and Management } \\
\text { (j-K6EM). ISSN: 2580-2135. Published by Graduate Program of } \\
\text { Educational Management, Universitas Lambung Mangkurat, }\end{array}$ \\
\hline
\end{tabular}

${ }^{*}$ Correspondence: Heri Pebriani; E-mail: febrianiheri@gmail.com 


\section{Introduction}

Improving the quality of education needs to be achieved by developing and enhancing human resources (Mantja, 2010).

To improve organizational effectiveness, Organ (1988) put forward five OCB dimensions namely (i) altruism; to help a specific other with organizationally relevant problems, (ii) conscientiousness; leads to behaviors that go beyond minimum work, (iii) sportsmanship; voluntary to tolerate less than ideal conditions without complaint, (iv) courtesy; prevent workrelated problems with other people; and (v) civic virtue; participate responsibly, engage in, or be concerned with the sustainability of the organization.

The OCB in Tanjung Redeb district Junior High Schools involves the behavior and attitudes of teachers in providing services to students, including extracurricular activities. Nevertheless, in the case of OCB is not well implemented, it means there is a lack of creativity and teacher initiative in carrying out their duties, schools need to offer additional tasks and policies. The low behavior of the teacher OCB deters the vision, mission, and goals of the school. In case schools are not able to run without an increase in the quality of teachers, OCB has a positive impact on school contributions.

D.J Weiss et al. in Jennifer and Garreth (2012) suggested indicators to measure job satisfaction are: (i) ability utilization; (ii) achievement; (iii) activity; (iv) advancement; (v) authority; (vi) company policies and practies; (vii) compensatioin; (viii) coworker; (ix) creativity; (x) moral values; (xi) recognition; (xii) responsibility; (xiii) security; (xiv) social service; (xv) social status; (xvi) human relation; (xvii) technical supervision; (xviii) variety; and (xix) working conditions.

Lack of Job satisfaction in Tanjung Redeb district Junior High Schools compromises the quality of the responsibilities. For instance, teachers work following the job description and do not display ability and knowledge. A satisfied teacher often performs as expected. In contrast, if a teacher is not satisfied, there might be an attitude of unwillingness to cooperate with other colleagues (Robbins, 2001).

Usman (2013) stated that leaders encourage subordinates to work as required by the organizational goals through various strategies, this includes motivation, which helps them to understand their work attitudes.
According to Wirawan (2013), two factors motivational theory proposed by Herzberg (1991) includes motivating: achievement, recognition, advancement, responsibility, work itself and healthy factors: interpersonal relations peers, supervision, security, policy and administration, working conditions, a salary which lead to job satisfaction and willingness to work.

Some teachers in Tanjung Redeb district Junior High Schools extend the resting period, complaining about trivial matters, and not implementing the rules established. Through this work motion, they might increase their work potential and perform beyond expectations.

Transformational leadership also has the potential to increase OCB. According to Avolio et al. (2004), transformational leaders encourage/motivation to subordinates to play an active role in the search for methods and assumptions to be realized in action. Bass and Avolio, revealed that influencing subordinates is known as the "4I" concept: (i) idealized influence; (ii) inspirational motivation; (iii) intellectual stimulation; and (iv) individual consideration (Titisari, 2014).

In general, the school organization has not been implemented optimally and this research has never been done. The situation and conditions as described above will have an influence/impact on the course of transformational leadership carried out by all school principals in Tanjung Redeb district High Schools, this problem, if not addressed, will cause problems for schools. To overcome this problem, OCB, job satisfaction, work motivation, and transformational leadership are considered.

The purpose of this study is to determine the contribution: (1) Regarding OCB, job satisfaction, work motivation and transformational leadership of the principal; (2) Transformational leadership of school principals at work motivation; (3) The principal's transformational leadership effect on job satisfaction; (4) The impact of work motivation on job satisfaction; (5) The principal's transformational leadership towards OCB; (6) Work motivation towards OCB; (7) Job satisfaction towards OCB; (8) The principal's transformational leadership indirect influence on work motivation; (9) The principal's transformational leadership indirectly towards OCB through job satisfaction; (10) Indirect work motivation towards OCB through job satisfaction; (11) The role of transformational leadership on work motivation. 


\section{Methodology}

This research uses a quantitative approach with descriptive methods, as shown in Figure 1.

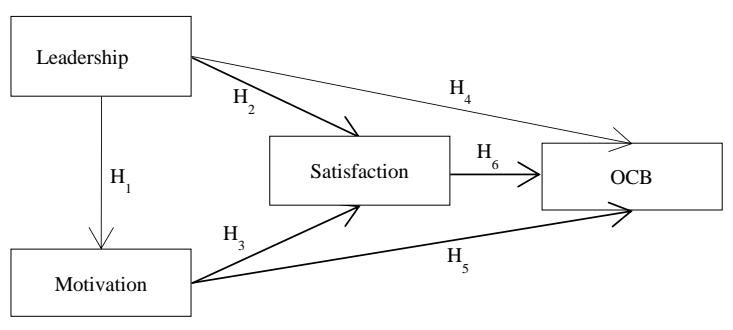

Figure 1. Research Model

The research population was 159 in junior high school teachers in the Tanjung Redeb district. The sample involved 114 teachers in 6 schools namely SMPN 1 totaling 22 people; SMPN 2 totaling 23 people; SMPN 3 totaling 22 people; SMPN 4 totaling 19 people; SMPN 5 totaling 14 people and SMPN 6 totaling 14 people; selected by stratified proportional random sampling. These were civil servants and honorary teachers.

Data were collected using a five scale model questionnaire, and validity tested using the Pearson Product Moment formula, and the correlation values obtained for all variables were above 0.361. Therefore, all the variables are valid, and the reliability test uses the Cronbach alpha formula. With a value of 0.6 , the instrument is declared reliable by choosing between one to five answers according to the actual conditions.
There are four questionnaires used in this research, including the OCB, job satisfaction, work motivation, and transformational leadership of school principals. The results of the regression calculations were taken through the classic assumption test, including normality, multicollinearity, linearity, and heteroscedasticity tests. Importantly, data were analyzed using path analysis.

\section{Findings and Discussion}

The results of the descriptive statistical analysis including OCB, job satisfaction, work motivation, and transformational leadership of the principal measured on a scale of 5 . The mean and standard deviations are shown in table 1.

The results of the classic assumption test include the OCB residual data normality test, job satisfaction, work motivation, and the transformational leadership of the principal using a scatter plot showing customarily distributed residuals. Multicollinearity test results indicate the tolerance value of each independent variable is above 0.1 and VIF below 10. The linearity test results show the relationship of leadership with work motivation and job satisfaction, leadership with OCB, work motivation with $\mathrm{OCB}$, and job satisfaction linear with OCB. Heteroscedasticity test results used scatter plot residual studentized regression diagram. In case the test results of the analysis requirements have been fulfilled, interpretation of the results of the path analysis was conducted, and the summary of results was as shown in Table 2, 3, 4 and 5.

Table I. Descriptive Research Variable Table

\begin{tabular}{lcccc}
\hline \multirow{2}{*}{ Variable } & Mean & Minimum & Maximum & $\begin{array}{c}\text { Std. } \\
\text { Deviation }\end{array}$ \\
\cline { 2 - 5 } & 3.6907 & 3.17 & 4.13 & .21713 \\
\hline OCB & 3.6811 & 3.08 & 4.13 & .20863 \\
\hline Job Satisfaction & 3.6720 & 3.00 & 4.06 & .21984 \\
\hline Work Motivation & 3.7152 & 3.10 & 4.13 & $.2206 \mathrm{I}$ \\
\hline $\begin{array}{l}\text { Transformational } \\
\text { Leadership }\end{array}$ & & & 4.13 & \\
\hline
\end{tabular}

Table 2. Summary of Path Analysis Results

\begin{tabular}{lccccc}
\hline \multirow{2}{*}{ Variable } & \multicolumn{5}{c}{ Transformational leadership - Teacher Work Discipline } \\
\cline { 2 - 6 } & Path coefficient & $\boldsymbol{T}$ & Sig & $\boldsymbol{R}^{2}$ & $\boldsymbol{F}$ \\
\hline $\begin{array}{l}\text { Transformational } \\
\text { Leadership }\end{array}$ & 0,367 & 4,170 & 0,000 & 0,314 & I7,39I \\
\hline Dep & & &
\end{tabular}

Dependent variable: Work Motivation. 
Table 3. Summary of Path Analysis Results

\begin{tabular}{lccccc}
\hline \multirow{2}{*}{ Variable } & \multicolumn{5}{c}{ Substructural 2 } \\
\cline { 2 - 6 } & Path coefficient & $T$ & Sig & $R^{2}$ & $F$ \\
\hline $\begin{array}{l}\text { Transformational } \\
\text { Leadership }\end{array}$ & 0,498 & 5,984 & 0,000 & 0,335 & 28,017 \\
\hline Work Motivation & 0,615 & I,990 & 0,049 & 0,335 & 28,017 \\
\hline Dependent variable: Job Satisfaction & & & & &
\end{tabular}

Table 4. Summary of Path Analysis Results

\begin{tabular}{lccccc}
\hline \multirow{2}{*}{ Variable } & \multicolumn{5}{c}{ Substructural 3 } \\
\cline { 2 - 6 } & Path coefficient & $T$ & Sig & $R^{2}$ & $F$ \\
\hline $\begin{array}{l}\text { Transformational } \\
\text { Leadership }\end{array}$ & 0,468 & 5,759 & 0,000 & 0,367 & 32,124 \\
\hline Work Motivation & 0,250 & 3,076 & 0,003 & 0,367 & 32,124 \\
\hline Dependent variable: OCB & & & & &
\end{tabular}

Table 5. Summary of Path Analysis Results

\begin{tabular}{lccccc}
\hline \multirow{2}{*}{ Variable } & \multicolumn{5}{c}{ Substructural 4 } \\
\cline { 2 - 6 } & Path coefficient & $T$ & Sig & $R^{2}$ & $F$ \\
\hline $\begin{array}{l}\text { Transformational } \\
\text { Leadership }\end{array}$ & 0,187 & 2,443 & 0,016 & 0,578 & 50, I3 I \\
\hline Work Motivation & 0,157 & 2,309 & 0,023 & 0,578 & 50, I3 I \\
\hline Job Satisfaction & 0,563 & 7,4 II & 0,000 & 0,578 & 50, I3 I \\
\hline Dependent variable: OCB & & & & &
\end{tabular}

Table 6. Summary of Direct Hypothesis Testing Decisions

\begin{tabular}{|c|c|c|}
\hline \multirow{2}{*}{ Hypothesis } & \multirow[b]{2}{*}{ Sig } & \multirow[b]{2}{*}{ Decisions } \\
\hline & & \\
\hline $\begin{array}{l}\text { H: There is a positive and significant contribution between leadership and work } \\
\text { motivation }\end{array}$ & 0,000 & Accepted \\
\hline $\begin{array}{l}\mathrm{H}_{2}: \text { There is a positive and significant contribution between leadership and job } \\
\text { satisfaction }\end{array}$ & 0,000 & Accepted \\
\hline $\begin{array}{l}\mathrm{H}_{3:} \text { There is a positive and significant contribution between work motivation and } \\
\text { job satisfaction }\end{array}$ & 0,049 & Accepted \\
\hline $\mathrm{H}_{4:}$ There is a positive and significant contribution between leadership and OCB & 0,016 & Accepted \\
\hline $\begin{array}{l}\text { Hs: There is a positive and significant contribution between work motivation and } \\
\text { OCB }\end{array}$ & 0,023 & Accepted \\
\hline $\begin{array}{l}\text { H6: There is a positive and significant contribution between job satisfaction and } \\
\text { OCB }\end{array}$ & 0,000 & Accepted \\
\hline
\end{tabular}

Table 7. Summary of Indirect Hypothesis Testing Decisions

\begin{tabular}{lccc}
\multicolumn{1}{c}{ Hypothesis } & $\mathrm{H}_{7} \mathrm{H}_{8} \mathrm{H}_{9}$ and $\mathrm{H}_{10}$ & & Sobel \\
\cline { 2 - 4 } & Test & Decisions \\
\hline $\begin{array}{l}\text { H: } \text { Work motivation is an intermediary for the contribution of leadership } \\
\text { to job satisfaction }\end{array}$ & $0,06 \mathrm{I}$ & Accepted \\
\hline H8: Job satisfaction is an intermediary for leadership contribution to OCB & 0,280 & Accepted \\
\hline H: Job satisfaction is an intermediary for work motivation contribution to & 0,093 & Accepted \\
\hline
\end{tabular}




\begin{tabular}{llll}
\hline \multirow{2}{*}{ Hypothesis } & $\mathrm{H}_{7} \mathrm{H}_{8} \mathrm{H}_{9}$ and $\mathrm{H}_{10}$ & & \\
\cline { 2 - 4 } & $\begin{array}{c}\text { Sobel } \\
\text { Test }\end{array}$ & Decisions \\
\hline $\mathrm{OCB}$ & & \\
\hline $\begin{array}{l}\mathrm{H}_{10}: \text { Work motivation is an intermediary for leadership contribution to } \\
\mathrm{OCB}\end{array}$ & 0,092 & Accepted \\
\hline
\end{tabular}

The path analysis results as shown in Table 3 are used to answer the six research hypotheses, and the decision is given in Table 3.6 and Table 3.7. In general, Table 3.6 summarizes the decisions of $\mathrm{H}_{1}, \mathrm{H}_{2}, \mathrm{H}_{3}, \mathrm{H}_{4}, \mathrm{H}_{5}$, and $\mathrm{H}_{6}$ with the criterion of a significance value of less than 0.05 , meaning the hypothesis is accepted. Table 3.7 is a summary of the hypothesis testing decisions $\mathrm{H}_{6}$, $\mathrm{H}_{7}, \mathrm{H}_{8}, \mathrm{H}_{9}$, and $\mathrm{H}_{10}$ in case the coefficient of the indirect relationship from the Sobel test is greater than $\mathrm{Z}$ table $1.65(\alpha=0.05)$.

Based on the results of the analysis in tables 3.6 and 3.7 above, the relationship between variables explained as follows.

There is a Significant and Positive relationship between Principal Transformational Leadership and Teacher Work Motivation.

This is evident from the path coefficient value of 0.367 , meaning the principal makes a direct contribution in providing motivation, inspiration, and ideas to the teacher. This is in line with previous research conducted by Normianti (2019), which established that there is a relationship between the principal's transformational leadership and the work motivation of South Labuan Amas teachers. This is evidenced by the success of the principal as a figure of leader boosting teacher creativity. The results of this research are supported by Avolio et al. (2004), which stated that transformational leaders motivate subordinates.

There is a significant and positive relationship between Principal Transformational Leadership and Teacher Job Satisfaction, and There is a as well as between Leadership and Job Satisfaction through Teacher Motivation.

Also, there is a relationship between principal transformational leadership and teacher job satisfaction, as seen from the path coefficient value of 0.498 . With increasing responsibility for the work carried out by the teacher, caring for coworkers, and being able to display their abilities and knowledge is a result of job satisfaction. These findings are in line with Ardiansyah (2013), which stated that there is a relationship between transformational leadership and organizational communication through job satisfaction of Hulu Sungai Tengah Junior High School teachers. This finding is also supported by
Robbins (2001), who stated that satisfaction increase in case direct superiors are friendly and understanding, showing performance, being an opinion listener, and showing interest in the work environment. Sobel test results through teacher work motivation were 0.061 , as evidenced by teachers who feel they are satisfied, and they share knowledge with other colleagues. This is supported by Rivai (2004), which stated that teachers feel that motivation is beneficial for the organization. The higher the individual's assessment work, the higher the satisfaction.

There is a significant and positive relationship between Work Motivation and Teacher Job Satisfaction. Similarly, there is also a positive relationship between Work Motivation and Teacher OCB through Job Satisfaction.

There is a relationship between work motivation and teacher OCB, and this is seen from the path coefficient value of 0.165 . This is proven by the increasing level of teacher discipline, creativity, a promising career path, and supportive working conditions. These findings are in line with Metriyadi (2016), which established that work motivation influences job satisfaction of the Lecturer. The differences between motivation and job satisfaction, where both of them are the same variable but do not guarantee the same impact on organizational behavior. Although Job Satisfaction is closely related to motivation theory, these two need to be treated separately for the influence factors and areas of practice to be further identified. Sobel test results through teacher job satisfaction of 0.093, show there is an encouragement from the in carrying out duties and enhance OCB behavior. Organ (1990) defines OCB as free individual behavior in determining an action, not directly recognized in the reward system, and encourage effective organizational functions.

There is a significant and positive contribution between the Principal Transformational Leadership and OCB, as well as between the Principal Transformational Leadership towards OCB through Teacher Job Satisfaction.

There is a relationship between the principal transformational leadership and OCB teachers. This is seen from the value of the path coefficient of 0.187 . The increasing types of OCB behavior 
greatly help the principal in every change and development in school, participate in every activity, and always take the initiative, innovative, and quality improvement within the organization. Teachers increasingly portray politeness towards their coworkers and avoid conflicts between them, helping the principal in leadership. OCB is essential in an organization, especially in the field of education, since it gives more influence. This is because it is an extra role behavior without any instructions from superiors. The results of this research are in line with Maulida (2019), which established that transformational leadership contributes to OCB Teacher MIN Se Banjarmasin City. The Sobel test results through teacher job satisfaction of 0.280 , is seen from the behavior displayed by the teacher due to a conducive atmosphere in carrying out OCB dimension forms and help leaders. Podsakoff et al. support these results and stated that Organizations benefit by encouraging employees to be directly involved in OCB since it increases productivity, efficiency, and customer satisfaction (Ahmad \& Khan, 2016).

There is a significant and positive relationship between Work Motivation and OCB through Job Satisfaction.

There is a relationship between work motivation and the OCB of the teacher. This is seen from the path coefficient value of 0.157 , which proves positive development. With the availability of adequate driving and health factors, the principal indirectly stimulates motivation and creates OCB behavior. The results also agree with Hasanah et al. (2018), which established there is a relationship between work motivation and OCB Teachers of Muhammadiyah Vocational High School. The Sobel test results through the work motivation of teachers were 0.092, as evidenced by the increasing interaction within the school environment and the expectations of teachers being achieved. The results of this research are reinforced by Ahmad et al. (2016) which stated that a leader needs to provide a complete package in motivating employees and therefore lead to OCB behavior.

There is a significant and positive relationship between Job Satisfaction and OCB Teachers. There is a relationship between job satisfaction and teacher OCB, as indicated by the path coefficient value of 0.563 . This resulted from job content, colleague attitudes, supervision, cooperation, and career opportunities provided by the job under the guidance of the principal. Increased teacher attendance at schools and increased mutual assistance/cooperation. These results are in line with Setiawan (2019), which established that there is a relationship between job satisfaction and OCB teachers of Banjarmasin Senior High Schools, Job satisfaction plays a significant role in increasing OCB.

\section{Conclusion and Recommendation}

This study concludes that there is a positive and significant relationship between the transformational leadership of the principal and teacher work motivation. Similarly, transformational leadership and job satisfaction are directly related. Also, there is an indirect relationship through teacher work motivation and job satisfaction. Moreover, there is an indirect relationship through teacher OCB, principal transformational leadership with job satisfaction with OCB through teacher work motivation, as well as work motivation with OCB and teacher job satisfaction with OCB teacher.

From the results, principals need to consider their transformational leadership to provide work motivation to teachers. Job satisfaction needs to be considered in order to create OCB behavior and advance school organizations.

\section{Acknowledgment}

The authors express their gratitude to the reviewer team and the Editor of the K6 Journal, Education, and Management, who allowed the results to be published.

\section{References}

Ahmad, S. W., \& Khan, T. (2016). Does motivation lead to organizational? a theoretical review. Global Journal of Management and Business Research: A Administration and Management, 16, (7), 2249-4588. Retrieved from http://www.pdfs.semanticscholar.org.

Ardiansyah. (2013). Hubungan kepemimpinan transformasional dan komunikasi organisasi dengan kepuasan kerja guru SMPN Hulu Sungai Tengah. (Unpublished master's thesis). Universitas Lambung Mangkurat, Banjarmasin, Indonesia.

Avolio, B. J., \& Bass, B. M. (2004). Traditional leadership: Charisma and beyond. MA: Livingstone Books.

Hasanah, R., Suriansyah, A., \& Ngadimun. (2018). Contributions of principals transformational leadership, teacher job satisfaction, organizational citizenship behavior (OCB) in Madrasah Ibtidaiyah (MIN) Banjarmasin, Indonesia. European Journal of Alternative Education Studies, 4, (1), 33-56. Retrieved from 
www.oapub.org/edu.

doi 10.5281/zenodo/2587591.

Jennifer, G., \& Garreth, J. R. (2012). Understanding and Managing Organizational Behavior. New Jersey: Pearson Education, Inc.

Mantja, W. (2005). Manajemen Pendidikan Dan Supervisi Pengajaran. Kumpulan Karya Tulis Terpublikasi. Malang: Wineka Media.

Maulida, H. (2019). Kontribusi Kepemimpinan Transformasional Kepala Madrasah Ibtidaiyah, Kepuasan Kerja Guru, Komitmen Organisasi Terhadap Organizational Citizenship Behavior (OCB) Guru Pada MIN Se-Kota Banjarmasin. (Unpublished master's thesis). Universitas Lambung Mangkurat, Banjarmasin, Indonesia.

Metriyadi. (2016). Pengaruh kecerdasan emosional dan motivasi kerja terhadap kepuasan kerja dosen Sekolah Tinggi Agama Hindu Negeri Penyang Palangkaraya. (Unpublished master's thesis). Universitas Lambung Mangkurat, Banjarmasin, Indonesia.

Normianti, H., Aslamiah, \& Suhaimi. (2019). Relationship of transformational leaders of principal, teacher motivation, teacher organization commitments with a performance of Primary School teachers in Labuan Amas Selatan, Indonesia. European Journal of Alternative Education Studies, 5, (1), 123-140. doi: 10.5281/zenodo.2583834.
Organ, D. W. (1988). Organizational Citizenship Behavior: The Good Soldier Syndrome. Lexington, MA: Lexington Books.

Organ, D. W. (1990). The motivational basis of organizational citizenship behavior. In B. M. Staw, \& L. L. Cummings (Eds.). Research In Organizational Behavior, 12, 43-72. Retrieved from http://www.academia.edu.

Rivai, V. (2004). Manajemen sumber daya manusia untuk perusahaan. Jakarta: Remaja Rosdakarya.

Robbins, S. P. (2001). Perilaku Organisasi, Terjemahan oleh Hadyana Pujatmaka \& Benyamin Molan. Jakarta: Prenhallindo.

Setiawan, T. B., Sulaiman, \& Metroyadi. (2019). Kepuasan Kerja sebagai perantara hubungan etos kerja, komitmen kerja dan OCB guru SMAN. Journal of K6, Educatioan, and Management (j-k6EM), 2, (1), 1-7.

Titisari, P. (2014). Peranan organizational citizenship behavior (OCB) dalam meningkatkan kinerja karyawan. Jakarta: Mitra Wacana Media.

Usman, H. (2013). Manajemen (Teori, Praktik Dan Riset Pendidikan). Edisi 4. Jakarta Timur: PT. Bumi Aksara.

Wirawan. (2013). Kepemimpinan (Teori, Psikologi, Perilaku Organisasi, Aplikasi dan Penelitian). Jakarta: PT. Raja Grafindo Persada. 